\title{
"Green" Water Treatment for the Green Industries: Opportunities for Biofiltration of Greenhouse and Nursery Irrigation Water and Runoff with Constructed Wetlands
}

\author{
R.D. Berghage and E.P. MacNeal \\ Department of Horticulture, The Pennsylvania State University, University Park, PA 16802 \\ E.F. Wheeler \\ Department of Agricultural and Biological Engineering, The Pennsylvania State University, University Park, \\ PA 16802 \\ W.H. Zachritz \\ The Southwest Technology and Development Institute, New Mexico State University, Las Cruces, NM 88003
}

\begin{abstract}
The green industries, including floriculture, ornamentals, turf, and landscape, are among the fastest growing segments of U.S. agriculture. Floriculture and nursery industry receipts increased $\approx 10 \%$ per year from 1986 to 1995 (Johnson and Christensen, 1995). In Pennsylvania, greenhouse and nursery products are the third largest agricultural commodity based on farm receipts. These products accounted for over \$300 million in wholesale farm value in Pennsylvania in 1995, or about three-fifths of all horticultural farm gate receipts (U.S. Dept. of Agriculture, 1995). This segment of commercial agriculture tends to be concentrated in and around urban population centers, is very visible to the nonfarm public, and has the potential to disproportionately impact both urban environments and public perceptions of agricultural chemical use.
\end{abstract}

Greenhouse and nursery production is high-intensity, high-input agriculture. Insecticides, fungicides, growth regulators, and other chemicals have been freely used to aid production. Fertilizer inputs, for example, can reach several thousand kilograms per hectare per year (Nelson, 1991). Fertility programs utilizing $\mathrm{N}$ at $200 \mathrm{mg} \cdot \mathrm{L}^{-1}$ or more during every irrigation are common. Peak water use, based on irrigation system design recommendations (Aldrich and Bartok, 1994), can exceed $180,000 \mathrm{~L} \cdot \mathrm{ha}^{-1}$ per day, generating 18,000 to $90,000 \mathrm{~L}$ of wastewater per hectare per day with traditional overhead hand or sprinkler irrigation. Although this seems wasteful, these inputs represent only a tiny fraction of the total cost of production, and hence have historically been ignored. This has, however, been changing over the last two decades as environmental, rather than economic, considerations have dictated a reevaluation of many common production practices.

Treatment and/or recycling of wastewater is mandatory for point source municipal and industrial water discharges in the United States (U.S. Congress, 1956, 1972). In a number of states this includes greenhouse and nursery growers (California Water Resources Control Board, 1969). Growers have developed elaborate and effective systems for recirculating irrigation and for treatment of wastewater to meet these demands (for example, see Skimna, 1986). Other states' regulations are not yet as stringent. However, greenhouses and nurseries have come under increased pressure to reduce wastewater discharge. Because conventional wastewater treatment techniques, such as air stripping, chemical oxidation, and carbon adsorption (Symons, 1981), are costly and may produce additional environmental problems, including sludge disposal, the industry has increasingly relied on water recycling and recirculating irrigation systems (Berghage, 1995). The purpose of this manuscript is to review the potential for pesticide contamination in greenhouse and nursery wastewater, particularly in recirculating irrigation systems, and to examine the possibilities for use of constructed wetlands to treat this water.

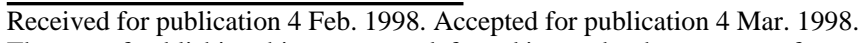
The cost of publishing this paper was defrayed in part by the payment of page charges. Under postal regulations, this paper therefore must be hereby marked advertisement solely to indicate this fact.

\section{PESTICIDE CONTAMINATION OF RECIRCULATING IRRIGATION SYSTEMS}

Recirculating irrigation systems offer the advantage of conserving water and eliminating discharge contaminated with fertilizer and pesticides. A disadvantage is that they may be prone to accumulation of residual contaminants, including fertilizer and nonfertilizer salts, pesticides, other chemicals, and plant pathogens (Berghage, 1997; Biernbaum, 1993; MacNeal and Berghage, 1996). For pesticide contamination to be a problem in recirculating irrigation systems, two conditions must be met: the pesticide must persist in the irrigation system, and must be capable of contaminating the reservoir.

\section{BIOLOGICAL FILTRATION WITH TREATMENT WETLANDS}

Biological filtration using low-cost constructed wetlands is an alternative for treating greenhouse and nursery wastewater and water contaminated in recirculating irrigation systems. Hundreds of treatment wetlands are being used throughout the world (Conley et al., 1991; Reed and Brown, 1992) to treat municipal, industrial, and agricultural wastewater; landfill leachate; and acid mine drainage (Anderson, 1993; Conley et al., 1991; Hammer, 1993). Both freewater surface wetlands and subsurface flow wetlands are thought to function as attached growth bioreactors, and each can effectively treat municipal wastes for biological oxygen demand (BOD) and total dissolved solids (TDS). Free-water surface treatment wetlands require larger land areas, and therefore may be less suitable for greenhouse and nursery water treatment where production area is generally at a premium. Further, because water may be contaminated with hazardous chemicals, the use of a bioremediation system in which the wastewater is not exposed is advantageous.

Subsurface treatment wetlands typically consist of a lined basin filled with a medium, usually coarse, gravel, that supports microbial populations and often higher plants. Treatment is achieved through physical, chemical, and biological interactions among the wastewater, the medium, and the organisms living there (Hammer, 1993). The medium in a subsurface treatment wetland provides a substrate for the growth of the biological components of the system, and may also provide for direct physical and chemical treatment of the wastewater. Filtration, adsorption, and chemical exchange can occur directly on the surface of the medium or in void spaces within (Reed et al., 1988). Particle size and density directly affect hydraulic conductivity and residence times, which in turn influence treatment efficacy (Conley et al., 1991).

\section{TREATMENT WETLAND FUNCTION}

The biological components of a treatment wetland transform, utilize, and sequester both organic and inorganic pollutants. Much of the breakdown, use, or transformation of contaminants is thought to be the result of aerobic and anaerobic microbial activities. Microorgan- 
isms provide most of the biological activity, resulting in BOD reduction and nitrogen removal. Microbes can also metabolize a wide range of organic contaminants such as benzene, naphthalene, toluene, and chlorinated aromatics (Evans and Fuchs, 1988; Kuhn and Sufilta, 1989; Wolverton and McDonald-McCaleb, 1986), petroleum hydrocarbons (Norris, 1994), and pesticides (Dobbins et al., 1992). Higher plants are not thought to be a major direct treatment mechanism for most water contaminants in treatment wetlands, but improved performance often occurs when plants are present (McIntyre and Riha, 1991; Shrimp et al., 1993; Wolverton et al., 1983).

\section{THE ROLE OF HIGHER PLANTS}

Plants may enhance contaminant removal by increasing active microbial populations or they may act directly on the contaminants. Populations of microbes are much higher in the rhizosphere than in the bulk medium (Papavizas and Davey, 1961). Emergent aquatic plants transport oxygen to their roots and the surrounding medium (Bedford et al., 1991; Sorrell and Armstrong, 1994). In a comparison of mechanical aeration vs. use of plants, reduction of BOD was considerably greater in the latter, and $90 \%$ of the oxygen transported to the effluent in the treatment wetland was attributed to plants (Reddy et al., 1989). Plants also provide a substantial carbohydrate source for microorganisms in the rhizosphere. Rhizodeposition and exudation of sugars, amino acids, enzymes, and numerous other compounds (Klein et al., 1990) can result in annual release of $7 \%$ to $27 \%$ of the total plant mass (Smith, 1990).

Plants may also function to remove or biologically alter water contaminants directly. Inorganic nutrient accumulation by plants temporarily removes these minerals from the water. Unless plants are harvested, these materials are eventually returned to the wetland tank. However, the chemical form may be altered. In contrast, complete mineralization is a realistic goal for many organic contaminants in treatment wetlands.

Plants can take up, and in some cases metabolize, a wide variety of organic chemicals, including organochlorine insecticides, benzene and substituted benzenes, and many other pesticides (Shrimp et al., 1993; Walton and Hoylman, 1992). The aquatic macrophyte water hyacinth, Eichhornia crassipes Solms-Laub., will remove phenols from polluted waters (Wolverton and McKown, 1976), and reed-based treatment wetlands can remove benzene, biphenyl, chlorobenzene, dimethylphthalate, ethylbenzene, naphthalene, $\mathrm{p}$-toluene, toluene, $\mathrm{p}$ xylene (Wolverton and McDonald-McCaleb, 1986), and benzoic acid (Zachritz et al., 1993). Although data are limited, aquatic macrophytes could play an important role in removing organic contaminants from greenhouse and nursery wastewater.

\section{MATERIALS AND METHODS}

To establish the potential for chemical contamination problems in recirculating irrigation systems, the commonly used fungicide metalaxyl [methyl $N$-(2,6-dimethylphenyl)- $N$-(methoxyacetyl)-DL-alaninate] $\left(\right.$ Subdue $\left.^{\mathrm{TM}}\right)$ and the plant growth regulator paclobutrazol [(2RS,3RS)1(4-chlorophenyl)-4,4-dimethyl-2-(1,2,4-triazol-1-yl)pentan-3-ol $\left(\right.$ Bonzi $\left.^{\mathrm{TM}}\right)$ were examined for long-term persistence in greenhouse reservoirs and residual concentrations following normal use.

Chemical persistence in irrigation reservoirs. Small (57 L) reservoirs connected to $\approx 8361 \mathrm{~cm}^{2}$ of subirrigation bench were treated with metalaxyl (Subdue 2E; CIBA Geigy, Greensboro, N.C.) to provide a final concentration in the reservoir of $\approx 30 \mathrm{mg} \cdot \mathrm{L}^{-1}$. A variety of plants were grown in 10.2-cm pots on the benches and irrigated using the water in the reservoir as needed. Metalaxyl concentration was determined using HPLC with a "NovaPak" C18 column (Millipore Corp., Milford, Mass.), with water and acetonitrile as the mobile phase, a diode array detector, and computer integration at $280 \mathrm{~nm}$ (Millennium System; Waters Corp., Milford, Mass.). Pure metalaxyl standards (Chem Service, West Chester, Pa.) were used to compare absorbance spectra and retention times and to estimate the quantity of metalaxyl in the water samples. Detection limits were $\approx 0.25 \mathrm{mg} \cdot \mathrm{L}^{-1}$ metalaxyl in raw samples. Trials were repeated four times with different people making the applications.
Paclobutrazol persistence was determined in a similar fashion; however, the reservoirs were not used to irrigate a crop, and the treatment rate was $1 \mathrm{mg} \cdot \mathrm{L}^{-1}$. Analysis was conducted by HPLC with detection limits of $\approx 0.1 \mathrm{mg} \cdot \mathrm{L}^{-1}$.

Contamination in irrigation reservoirs. Metalaxyl $(150 \mathrm{~mL})$ was applied as a drench at the recommended rate $\left(0.16 \mathrm{~mL} \cdot \mathrm{L}^{-1}\right)$ to plants on subirrigation trays, exercising care to avoid contamination of the flood irrigation system. The volume of drench solution used was predetermined to be sufficient to saturate the average pot root zone without excess. Residual contamination in the reservoir was determined as above.

Residual paclobutrazol in irrigation reservoirs was determined following both drench and spray applications to bedding plants on two $6.8-\mathrm{m}^{2}$ subirrigation benches. Each bench was connected to a $189-\mathrm{L}$ reservoir. The concentration of paclobutrazol for both sprays and drenches was $10 \mathrm{mg} \cdot \mathrm{L}^{-1}$.

Treatment wetlands. Treatment wetlands for greenhouse or nursery use should be simple, inexpensive, and easy to build and maintain. The systems used in these studies were oval-shaped 189- and 378-L high-density polyethylene (HDPE) livestock watering tanks with tank depths of 0.25 and $0.65 \mathrm{~m}$, respectively. Both had a top surface area of $0.66 \mathrm{~m}^{2}$. Preliminary comparative trials suggested that $189-\mathrm{L}$ tanks outperformed 378-L tanks, so most of the work was done using 189L tanks. A bulkhead fitting connected to a standpipe at one end was used to regulate water level in the tank. Test systems were constructed with sampling ports in the front, middle, and back of the tanks at the bottom, mid-strata, and surface. When filled to within $3 \mathrm{~cm}$ of the top, the tanks provided void space ratios from 0.20 to 0.37 , depending on the size of the gravel medium. Volume of liquid in the tanks ranged from 40 to $140.4 \mathrm{~L}$. These systems were operated in flow-through and batch treatment modes with estimated residence times ranging from 1 $\mathrm{d}$ to over 3 months. The most effective procedure was to apply wastewater to the surface and withdraw the treated water from the bottom. All tests involved treatment systems both with and without plants. Planted wetlands have used Scirpus validus Vahl., Phragmites sp. Trin., and Iris pseudacoras L.

Removal of chlorinated phenolics by treatment wetlands. Constructed wetlands operated with a 1 to $2 \mathrm{~d}$ average residence time were treated with phenol, trichlorophenol, and pentachlorophenol. Chlorinated phenolics were selected as preliminary test chemicals for ease of analysis and because they represent a range of potentials for biodegradation. Pentachlorophenol is also an EPA priority pollutant. Experiments were conducted with tanks batch loaded with $10 \mathrm{~L}$ of phenol, sodium trichlorophenolate (TCP), and sodium pentachlorophenolate (PCP), each at $10 \mathrm{mg} \cdot \mathrm{L}^{-1}$. Separate experiments were also conducted with a continuous input stream of regularly increasing concentrations of TCP or PCP. A bromide tracer was added to batch treatments to provide a standard for recovery analysis. Samples were collected from the various sample ports and analyzed for phenolics with HPLC, and for bromide using a specific ion electrode.

Removal of metalaxyl by treatment wetlands. Constructed wetlands operated in a recirculating mode were treated with metalaxyl. In these trials the output reservoir was used to supply input. Solution was pumped from the output reservoir to the input end of the tank at a rate corresponding to a theoretical residence time of $2 \mathrm{~d}$. The metalaxyl input was calculated, based on void volume, to result in a concentration of $4 \mathrm{mg} \cdot \mathrm{L}^{-1}$ throughout the wetland with no treatment. Water samples were collected from the output standpipe and assayed for metalaxyl using HPLC.

\section{RESULTS AND DISCUSSION}

Chemical persistence in irrigation reservoirs. Metalaxyl concentration in the irrigation reservoirs did not change appreciably during the evaluation period (Fig. 1), except through dilution, when additional water was added to the system to replace water used by the plants. As in natural waters, where it can persist for more than 12 weeks (Sharom and Edgington, 1982), metalaxyl in recirculating irrigation reservoirs was stable. Paclobutrazol concentrations in greenhouse reservoirs also were stable over a 3-month period (Fig. 2). 


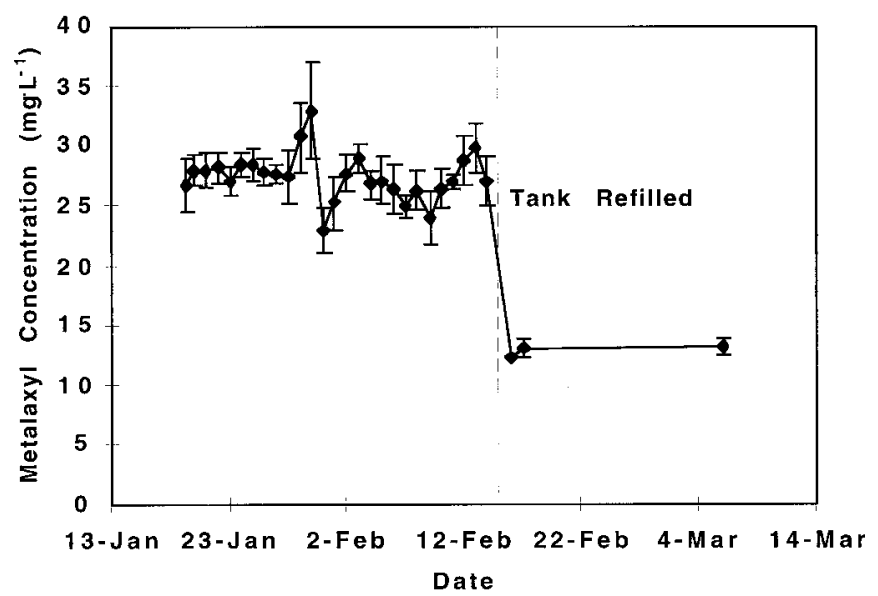

Fig. 1. Metalaxyl concentration in recirculating irrigation reservoirs dosed with $30 \mathrm{mg} \cdot \mathrm{L}^{-1}$. Tanks were refilled with clear water on $15 \mathrm{Feb}$. Vertical bars indicate \pm SD.

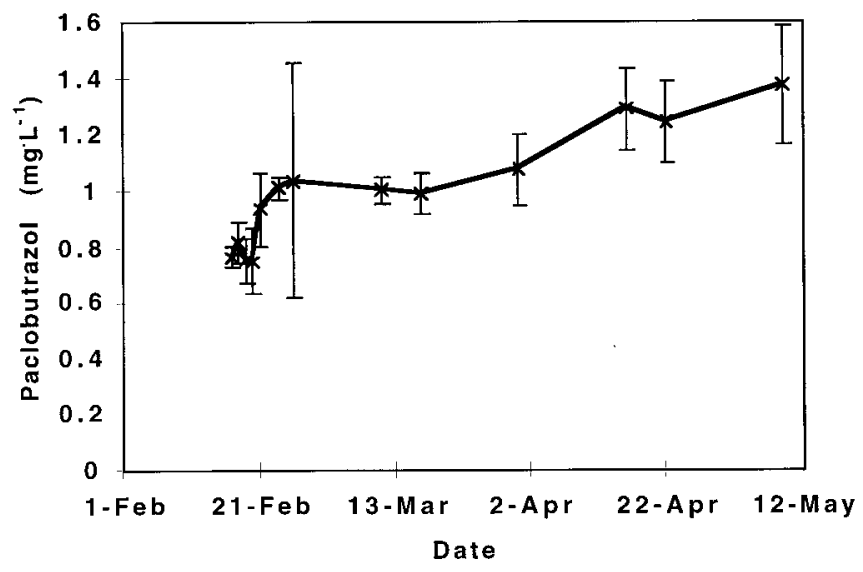

Fig. 2. Persistence of $1 \mathrm{mg} \cdot \mathrm{L}^{-1}$ paclobutrazol in irrigation reservoirs in a greenhouse. Five reservoirs treated with $1 \mathrm{mg} \cdot \mathrm{L}^{-1}$ of paclobutrazol were sampled periodically from 17 Feb. through 9 May. Water was not used for irrigation. Vertical bars indicate \pm SD.

Contamination in irrigation reservoirs. Normal drench applications of metalaxyl and paclobutrazol resulted in 1 to $4 \mathrm{mg} \cdot \mathrm{L}^{-1}$ and 0.1 to $0.5 \mathrm{mg} \cdot \mathrm{L}^{-1}$ residual concentrations in irrigation reservoirs, respectively (Fig. 3), whereas spray applications of paclobutrazol resulted in concentrations of 0.01 to $0.05 \mathrm{mg} \cdot \mathrm{L}^{-1}$ in the irrigation reservoir. Although these solutions were carefully applied, in each case leaching and surface residual clearly were sufficient to contaminate the reservoir. Drenches in commercial greenhouses are often applied with a hose and injector, presumably resulting in less uniformity, more leaching, and greater spillage on the bench surface, and, hence, an even greater potential for contamination.

The metalaxyl trials have been repeated five times with four different people applying the pesticides, with similar results each time. This suggests that significant potential exists for contamination of recirculating irrigation systems with low levels of the pesticides used in crop production. These results also demonstrate that metalaxyl and paclobutrazol, and probably other pesticides as well, can persist in the reservoir for extended periods.

Although the spread of water-borne pathogens in recirculated irrigation water has not proven to be the problem once anticipated (George, 1989; Molitor, 1989), there have been several unpublished reports of pathogens that are resistant to metalaxyl in these systems. Exposure of pathogens to low-level residuals of this fungicide in irrigation reservoirs may be providing selection pressure for resistant organisms. Bruin and Edgington (1981) selected metalaxyl-resistant Pythium and Phytophthora species by culturing with sublethal metalaxyl concentrations, and metalaxyl-resistant pathogens have been reported

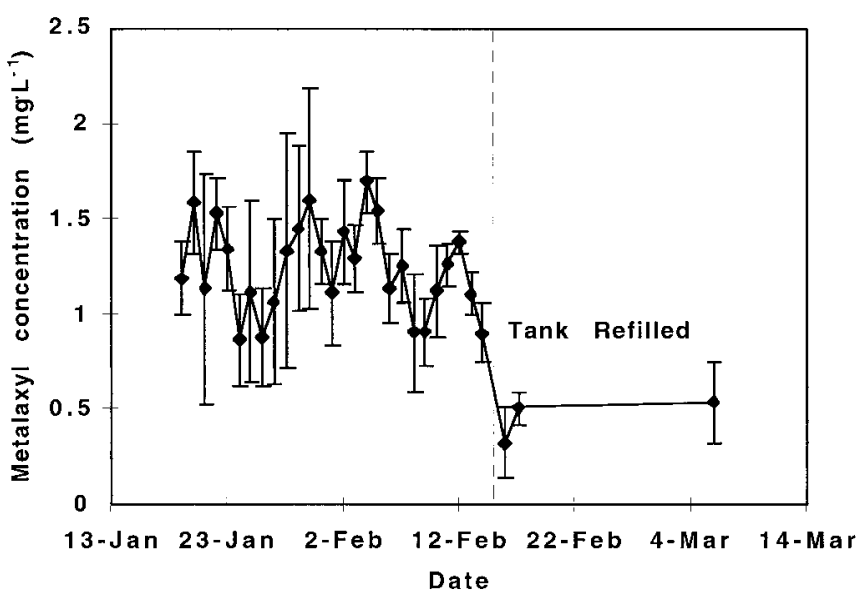

Fig. 3. Residual metalaxyl in recirculating irrigation reservoirs following a drench application of $150 \mathrm{~mL} 0.16 \mathrm{~mL} \cdot \mathrm{L}^{-1}$ metalaxyl to each $10.2-\mathrm{cm}$ pot. Tank were refilled with clear water on 15 Feb. Vertical bars indicate \pm SD.
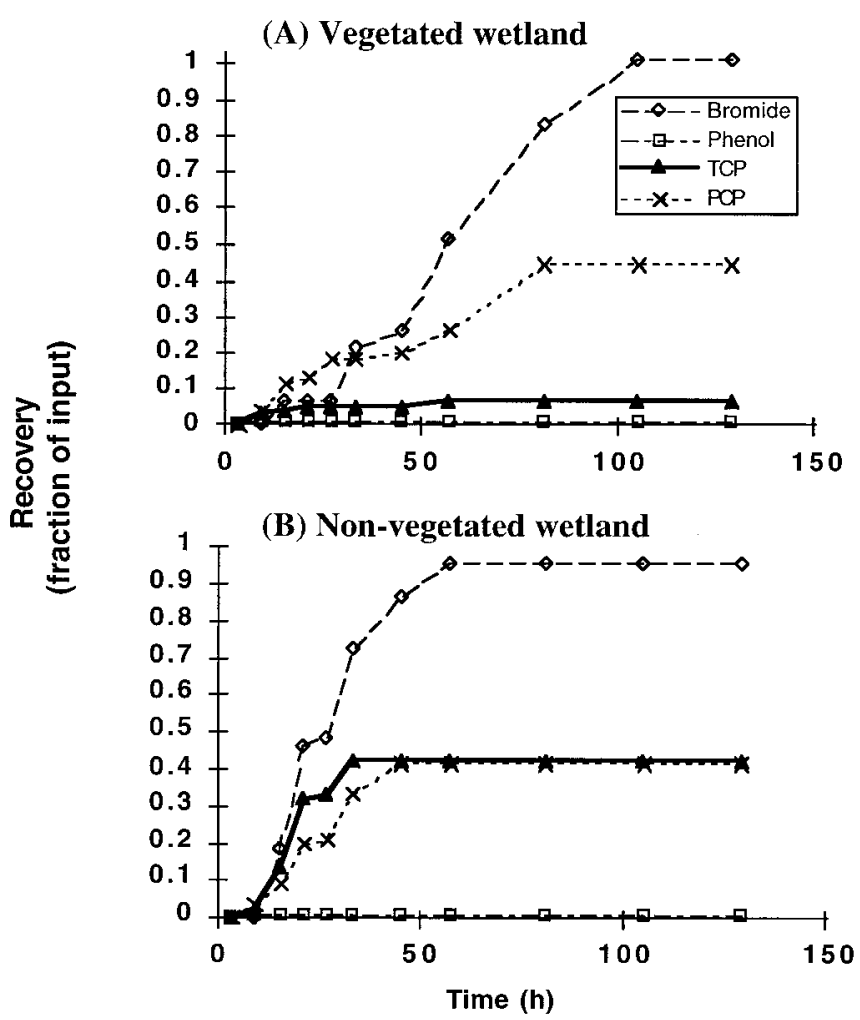

Fig. 4. Removal of batch loaded phenol, trichlorophenol (TCP), and pentachlorophenol (PCP) from water in (A) vegetated and (B) nonvegetated constructed wetlands. Bromide was used as a tracer.

in cucumber and tomato greenhouses in Greece (Georgopoulos and Grigoriu, 1981; Pappas, 1985). The presence of chemical residuals in the recirculating irrigation reservoir is a risk not only from the standpoint of the development of resistant pathogens, but may also be a hazard to workers or to the crop under production, and certainly presents a hazard to surface and ground water supplies if discharged as waste.

Removal of chlorinated phenolics by treatment wetlands. Plants improved the performance of treatment wetlands in removing TCP but not the more highly chlorinated PCP. When operated with a 1 to $2 \mathrm{~d}$ average residence time and batch loaded with TCP and PCP, tanks with plants were more effective at removal of TCP than were those without plants. In contrast, plants had no effect on PCP removal (Fig. $4 \mathrm{~A}$ and $\mathrm{B})$. 

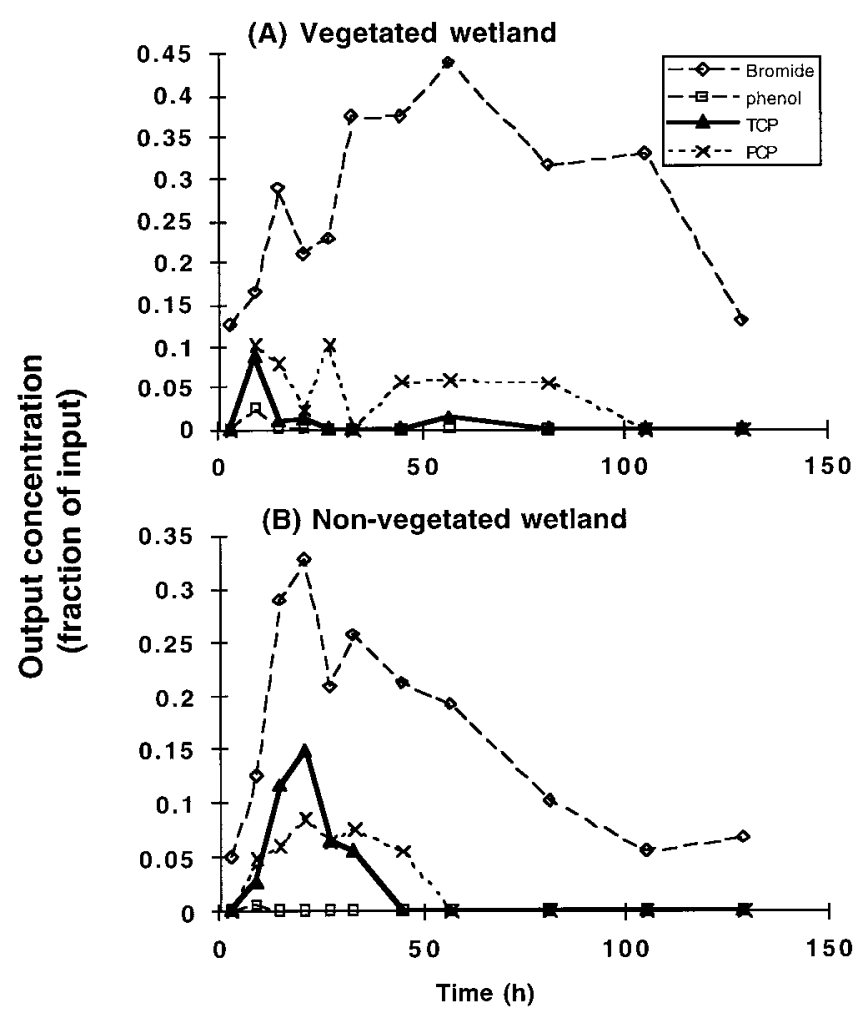

Fig. 5. Output of batch loaded phenol, trichlorophenol (TCP), pentachlorophenol (PCP), and bromide tracer from (A) vegetated and (B) nonvegetated constructed wetlands.

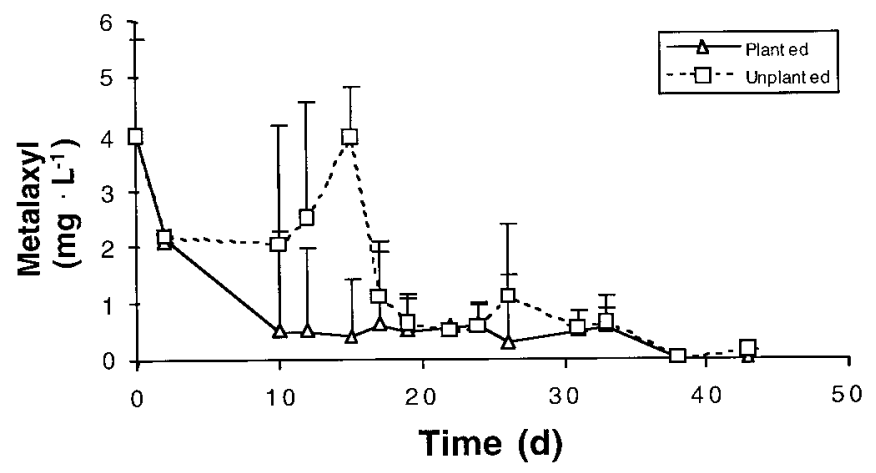

Fig. 6. Metalaxyl concentration in the output of planted and unplanted treatment wetlands. Vertical bars indicate \pm SD.

The difference in treatment activity between planted and unplanted wetlands was observed primarily in the lower strata within the tanks. Very little TCP or PCP was observed in the middle or bottom strata of the tanks with plants. Concentrations of TCP and PCP in the middle and lower strata of the tanks without plants were higher, reaching about the same concentration as the surface samples $\left(\approx 1 \mathrm{mg} \cdot \mathrm{L}^{-1}\right)$ after $10 \mathrm{~h}$. Bromide tracer concentrations in samples from these locations were not affected by the presence of plants, suggesting that the plants contributed directly or indirectly to the removal of TCP in these strata of the treatment wetlands.

Less than $10 \%$ of the applied TCP was recovered at the outlet from the system with plants, and most of this reached the outlet in the first $12 \mathrm{~h}$ (Fig. 5A). Only a very small peak in TCP in the effluent coincided with the apparent residence time $(\approx 50 \mathrm{~h}$ based on maximal bromide tracer output). The early peak in TCP $($ at $\approx 10 \mathrm{~h})$ was probably the result of untreated flow across the surface. In the tank without plants, $\approx 40 \%$ of the applied TCP was recovered in the effluent, and the pattern of TCP recovery followed the pattern for bromide recovery (Fig. 5B). With a continuous input of $25 \mathrm{mg} \cdot \mathrm{L}^{-1} \mathrm{TCP}$, steady-state output from tanks with plants averaged $1.6 \mathrm{mg} \cdot \mathrm{L}^{-1}$, while that from tanks without plants averaged $4.9 \mathrm{mg} \cdot \mathrm{L}^{-1}$. There were no significant differences between wetlands planted with Scirpus or Phragmites. Total PCP recovered as a percentage of input was not affected appreciably by the presence of plants (Fig. $4 \mathrm{~A}$ and B). Treatment wetlands, either planted or unplanted, were much less capable of removing PCP. Steady-state output levels between 1 and $6 \mathrm{mg} \cdot \mathrm{L}^{-1}$ were obtained with $16 \mathrm{mg} \cdot \mathrm{L}^{-1}$ continuous input of PCP.

No residual PCP or TCP was found in plant and sediment samples collected after the experiments were terminated. Although this does not indicate the fate of the chemicals, it does suggest that they did not simply accumulate in the systems in an extractable form.

Removal of metalaxyl by treatment wetlands. As with TCP and $\mathrm{PCP}$, trials with the fungicide metalaxyl suggest that it can be removed from contaminated water by either planted or unplanted wetlands. The removal rate for metalaxyl was greater in systems with plants, but, given enough time, the tanks without plants were equally effective (Fig. 6). For greenhouse wastewater treatment using constructed wetlands, tanks with or without plants may be housed in the greenhouse environment. In commercial greenhouses, the use of systems without plants might be preferable, as valuable production space would not be used. An unplanted biofilter could be placed under a greenhouse bench or in another nonproductive area. As with TCP and $\mathrm{PCP}$, no residual metalaxyl was recovered in assays of plant or sediment samples.

\section{DESIGN AND CONSTRUCTION OF TREATMENT WETLANDS FOR GREENHOUSE USE}

The size of a wetland needed to treat greenhouse wastewater and/ or irrigation water (the number of tanks in series or parallel) can be calculated based on the volume of wastewater, the residence time required to achieve the desired level of remediation, and the void volume of the system. Wetland size needed to treat a recirculating irrigation system is directly related to the size of the irrigation reservoir and the fraction of the return water being treated. Wetland size could be altered by changing the wetland medium (void volume), the tank depth, or the required residence time. Void volume is primarily constrained by particle size and structure. The depth is limited by the distribution of aerobic and anaerobic microorganisms and the root zone of higher plants. Aerobic processes will be greatly limited near the bottom of deep tanks unless mechanical or biological (higher plants) aeration is utilized. Required residence time is a function of the number and activity of the biological components and the removal rate of the contaminants of interest.

\section{SUMMARY}

Data obtained to date suggest that biological filtration using constructed wetlands is an alternative for treating greenhouse and nursery waste and irrigation water. Both planted and unplanted wetlands can effectively remove organic contaminants, reducing the potential for environmental contamination, chemical carryover from one crop to the next, or development of resistant pathogens from continuous exposure to low-level pesticide residuals. Although systems with plants appear to be more robust, in many cases removing contaminants more quickly, those without plants have the advantage of not using productive space. Provided that differences in effectiveness between planted and unplanted systems can be accommodated in either increased residence time or increased system size, unplanted biofilters may be a better choice.

More research is needed on constructed wetland biological filters to verify their effectiveness with additional greenhouse chemicals. Removal rates for target chemicals in planted and unplanted treatment wetlands are needed to determine design criteria to achieve desired treatment results. This will allow potential users to better compare costs and benefits associated with using planted or unplanted constructed wetland biofilters to clean irrigation and wastewater. Longterm studies are needed to examine the "life expectancy" of the treatment tanks, including potential disposal requirements for any chemical residuals left in the tank at the end of its useful life. 


\section{Literature Cited}

Aldrich, R.A. and J.W. Bartok. 1994. Greenhouse engineering. 3rd rev. NRAES-33. Northeast Regional Agr. Eng. Serv., Ithaca, N.Y.

Anderson, P. 1993. Constructed wetlands are a sweet deal. Water Environ. and Tech. July. p. 56-59.

Bedford, B.L., D.R. Bouldin, and B.D. Beliveau. 1991. Net oxygen and carbondioxide balances in solutions bathing roots of wetland plants. J. Ecol. 79:943-959.

Berghage, R.D. 1995. The three R's for greenhouse water use: Reduce, reuse, and recycle. Ohio Florists Assn. Bul. 784:1, 11-13.

Berghage, R.D. 1997. Reduce irrigation runoff contamination and costs. GMPro 17(8):57-59.

Biernbaum, J. 1993. Subirrigation: Does it make sense for your operation? PPGA News 24(4):2-5, 10-11, 14.

Bruin, G.C.A. and L.V.Edgington. 1981. Adaptive resistance in Peronosporales to metalaxyl. Can. J. Plant Path. 3:201-206.

California State Water Resources Control Board. 1969. California Statute 482:1052.

Conley, L.M., R.I. Dick, and L.W. Lion. 1991. An assessment of the root zone method of wastewater treatment. Res. J. Water Pollution Control Fed. 63:239-247.

Dobbins, D.C., C.M. Aelion, and F. Pfaender. 1992. Subsurface, terrestrial microbial ecology and biodegradation of organic chemicals: A review. CRC Rev. in Env. Control 22(1/2):67-136.

Evans, W.C. and G. Fuchs. 1988. Anaerobic degradation of aromatic compounds. Annu. Rev. Microbiol. 42:289-317.

George, R.K. 1989. Flood subirrigation systems for greenhouse production and the potential for disease spread. MS Thesis, Michigan State Univ., East Lansing.

Georgopoulos, S.G. and A.C. Grigoriu. 1981. Metalaxyl-resistant strains of Pseudoperonospora cubensis in cucumber greenhouses of southern Greece. Plant Dis. 65:729-731.

Hammer, D. 1993. Designing constructed wetlands systems to treat agricultural nonpoint source pollution, p. 71-114. In: R.K. Olsen (ed.). Created and natural wetlands for controlling nonpoint source pollution. C.K. Smoley, Boca Raton, Fla.

Johnson, D.C. and R.L. Christensen. 1995. The green industry today - some issues and future prospects. J. Agr. Business 13(1):63-76.

Klein, D.A., J.L. Salzwedel, and F.B. Dazzo. 1990. Microbial colonization of plant roots, p. 189-225. In: J.P. Nakas and C. Hagedorn (eds.). Biotechnology of plant microbe interactions. McGraw Hill, New York.

Kuhn, E.P. and J.M. Suflita. 1989. Dehalogenation of pesticides by anaerobic microorganisms in soils and groundwater-A review, p. 111-180. In: B.L. Sawhney and K. Brown (eds.). Reactions and movement of organic chemicals in the soil. SSSA Spec. Publ. No. 22. Soil Sci. Soc. of Amer., Madison, Wis.

MacNeal, E.P. and R.D. Berghage. 1996. Biofiltration of metalaxyl residue in recirculating irrigation water using constructed wetlands. HortScience 31:655.

McIntyre, B.D. and S.J. Riha. 1991. Hydraulic conductivity and nitrogen removal in an artificial wetland system. J. Env. Qual. 20:259-263.

Molitor, H.D. 1989. The European perspective with emphasis on subirrigation and recirculation of water and nutrients. Acta Hort. 272:165-174.

Nelson, P.V. 1991. Greenhouse operation and management. 4th ed. PrenticeHall, Englewood Cliffs, N.J.
Norris, R.D. 1994. In situ bioremediation of soils and ground water contaminated with petroleum hydrocarbons, p. 17-37. In: R.D. Norris, R.E. Hinchee, R. Brown, P.L. McCarty, L. Semprini, J.T. Wilson, D.H. Kampbell, M. Reinhard, E.J. Bouwer, R.C. Borden, T.M. Vogel, J.M. Thomas, and C.H. Ward (eds.). Handbook of bioremediation. Lewis, Boca Raton, Fla.

Papavizas, G.C. and C.B. Davey. 1961. Extent and nature of the rhizosphere of Lupinus. Plant Soil 14:215-236.

Pappas, A.C. 1985. Metalaxyl resistance in Phytophthora infestans on greenhouse tomatoes in Greece. Plant Path. 34:293-296.

Reddy, K.R., E.M. D’Angelo, and T.A. DeBusk. 1989. Oxygen transport through aquatic macrophytes: The role in wastewater treatment. J. Env. Qual. 19:261-267.

Reed, S.C. and D.S. Brown. 1992. Constructed wetland design-The first generation. Water Env. Res. 64:776-781.

Reed, S.C., E.J. Middlebrooks, and R.W. Crites. 1988. Natural systems for waste management and treatment. McGraw-Hill, New York.

Sharom, M.S. and L.V. Edgington. 1982. The adsorption, mobility, and persistence of metalaxyl in soil and aqueous systems. Can. J. Plant Path. 4:334-340.

Shrimp, J.F., J.C. Tracy, L.C. Davis, E. Lee, W. Huang, and L.E. Erikson. 1993. Beneficial effects of plants in the remediation of soil and groundwater contaminated with organic materials. Critical Rev. Env. Sci and Technol. 23(1):41-77.

Skimna, C.A. 1986. Recycling irrigation runoff on container ornamentals. HortScience 21:32-34.

Smith, W.H. 1990. The atmosphere and the rhizosphere: Linkages with potential significance for forest tree health, p. 188-241. In: A.A. Lucier and S.H. Haines (eds.). Mechanisms of forest response to acidic deposition. Springer Verlag, New York.

Sorrell, B.K. and W. Armstrong. 1994. On the difficulties of measuring oxygen release by root systems of wetland plants. J. Ecol. 82:177-183.

Symons, J.M. 1981. Treatment techniques for controlling trihalomethanes in drinking water. USEPA 600/2-81-156.

U.S. Congress. 1956. Water pollution control act. Public law 84-660. 70 Statute 498.

U.S. Congress. 1972. Amendments to the Water Pollution Control Act. Public Law 92-500. 86 Statute 816-904.

U.S. Department of Agriculture. 1995. Floriculture crops 1995 summary. USDA NASS SP Cr 6-1(96).

Walton, B.T. and A.M. Hoylman. 1992. Uptake, translocation, and accumulation of polycyclic aromatic hydrocarbons in vegetation. Electrical Power Res. Inst. Rpt. TR-101651, EPRI, Palo Alto, Calif.

Wolverton, B.C. and M.M. McKown. 1976. Water hyacinths for removal of phenols from polluted waters. Aquatic Bot. 2:191-201.

Wolverton, B.C., R.C. McDonald, and W.R. Duffer. 1983. Microorganisms and higher plants for wastewater treatment. J. Env. Qual. 12:236-242.

Wolverton, B.C. and R.C. McDonald-McCaleb. 1986. Biotransformation of priority pollutants using biofilms and vascular plants. J. Miss. Acad. Sci. 31:79-89.

Zachritz, W.H., L.L. Lundie, and N.N. Khandan. 1993. Constructed wetlands systems for advanced treatment of complex organic wastewaters: Industrial and agricultural impact on the hydrologic environment, p. 221-237. In: Y. Eckstein and A. Zaporozec (eds.). Water management and protection. Water Env. Fed., Alexandria, Va. 